\title{
FARKLI ORANLARDA PEYNİR ALTI SUYU KULLANIMININ BEYAZ VE TAM BUĞDAY UNLARINDAN ÜRETİLEN EKMEKLERIN BAZI ÖZELLİKLERİ ÜZERİNE ETKİSİ
}

\author{
Zeynep Cans1z', Cihadiye Candal Uslu ${ }^{2,3, *}$, Ceren Mutlu' ${ }^{2,4}$, \\ Sultan Arslan Tontul ${ }^{5}$, Recai Ercan ${ }^{1}$, Mustafa Erbaş ${ }^{2}$ \\ 1 Ankara Üniversitesi, Mühendislik Fakültesi, Gıda Mühendisliği Bölümü, Ankara, Türkiye \\ 2 Akdeniz Üniversitesi, Mühendislik Fakültesi, Gıda Mühendisliği Bölümü, Antalya, Türkiye \\ 3 Artvin Çoruh Üniversitesi, Sağlık Bilimleri Fakültesi, Beslenme ve Diyetetik Bölümü, Artvin, Türkiye \\ ${ }^{4}$ Balıkesir Üniversitesi, Mühendislik Fakültesi, Gıda Mühendisliği Bölümü, Balıkesir, Türkiye \\ ${ }^{5}$ Selçuk Üniversitesi, Ziraat Fakültesi, Gıda Mühendisliği Bölümü, Konya, Türkiye
}

Geliş / Received: 26.03.2019; Kabul / Accepted: 09.12.2019; Online bask1 / Published online: 29.01.2020

Cansız, Z., Candal Uslu, C., Mutlu, C., Arslan Tontul, S., Ercan, R., Erbaş, M. (2020). Farklı oranlarda peynir altı suyu kullanımının beyaz ve tam buğday unlarından üretilen ekmeklerin bazı özellikleri üzerine etkisi. GID $A$ (2020) 45(1) 125-138 doi: 10.15237/gida.GD19066

Cansız, Z., Candal Uslu, C., Mutlu, C., Arslan Tontul, S., Ercan, R., Erbas, M. (2020). The effects of whey addition at different ratios on the properties of breads produced from white and whole wheat flour. GIDA (2020) 45(1) 125-138 doi: 10.15237/gida.GD19066

\section{ÖZ}

Dünya genelinde sağlık sorunlarının artışı, yaşam kalitesini bozan beslenme ve çevre sorunlarıyla ilişkilendirilmektedir. Bunun sonucu olarak, insanların sağlıklı bir çevreye ve zengin besin içeriğine sahip gıdalara talebi artmaktadır. Bu çalısmada, beyaz un ve tam buğday unu ile üretilen ve üretim aşamasında su yerine beş farklı oranda ( $\% 0$-kontrol, $\% 25, \% 50, \% 75$ ve $\% 100)$ peynir altı suyu (PAS) ilave edilerek besinsel içeriği zenginleştirilen ekmeklerin fiziksel, kimyasal ve duyusal özelliklerinde meydana gelen değişimlerin ve PAS’in hamur oluşturma suyu olarak kullanılabilirliğinin araştırılması amaçlanmıştur. Araştırma sonucunda PAS oranının artmasıyla; ekmeklerin kabuk renklerinin koyulaştı̆̆ı, HMF içeriğinin arttığ1 ve sertlik değerinin azaldığı belirlenmiştir. Ayrıca PAS kullanılarak üretilen tüm ekmekler panelistler tarafindan 5 puanlık hedonik skalada orta değer olan 3 ve üzerinde puanlanmıstır. Sonuç olarak; PAS'ın ekmek üretiminde \%50’ye kadar hamur suyu ikamesi olarak kullanılabileceği ve böylelikle besin içeriğince zengin olan bu ürünün çevreye atık olarak salınması yerine hamura katılarak ekmeğin besleyici özelliklerini ilave masraf olmadan geliştirebileceği değerlendirilmiştir.

Anahtar kelimeler: Peynir altı suyu, çevre, ekmek, HMF

\section{THE EFFECTS OF WHEY ADDITION AT DIFFERENT RATIOS ON THE PROPERTIES OF BREADS PRODUCED FROM WHITE AND WHOLE WHEAT FLOUR}

\begin{abstract}
Increasing health problems in worldwide relate to the nutritional and environmental problems affected life quality negatively. Therefore, people's demands to the healthy environment and nutritional foods increased. In this study, bread production was performed by using white and whole wheat flour with the whey addition ( $0 \%$-control, $25 \%$, $50 \%, 75 \%$ and $100 \%$ ). This study aimed examining the changes in some properties of these breads, and investigation of whey usage as dough water. As a result; as the whey ratio increased, the breads' crust colour became darker, HMF content increased and hardness decreased. Also, all breads were scored 3 or more points on the hedonic scale. Consequently; it was evaluated that whey can be used up to $50 \%$ as dough water in bread production. Thus, this product can be added to the dough instead of releasing to the environment as waste and it can improve the bread's nutritional properties without additional costs.
\end{abstract}

Keywords: Whey, environment, bread, HMF

\footnotetext{
* Yazışmalardan sorumlu yazar / Corresponding author;

$\checkmark$ cihadiyecandal@artvin.edu.tr (0 (+90) 2423106575

司(+90) 2423106306
}

Zeynep Cansız; ORCID no: 0000-0001-8615-4737

Cihadiye Candal Uslu; ORCID no: 0000-0002-5945-6649

Ceren Mutlu; ORCID no: 0000-0003-4943-2798

Sultan Arslan Tontul; ORCID no: 0000-0003-1557-7948

Recai Ercan; ORCID no: 0000-0001-8151-6786

Mustafa Erbaş; ORCID no: 0000-0002-9485-2356 


\section{GİRİ̧̧}

Dünya genelinde sağlık sorunlarının artması ve Dünya Sağlık Örgütü'nün protein ve enerji yetersizliğini yaşam kalitesini bozan beslenme sorunlarından birisi olarak kabul etmesi ile birlikte bilinçli g1da tüketim konusu büyük önem kazanmıştır (Pekcan, 2009). Bu nedenle, tüketicilerin beslenme alışkanlıklanında değişiklikler meydana gelmiş ve sağlık üzerine olumlu etkileri bulunan fonksiyonel gidalara normal diyet düzeni içerisinde daha çok yer verilmeye başlanmıştır (Gonçalves Cibely vd., 2017; Salazar vd., 2017). Bu kapsamda peynir alt1 suyu (PAS) gibi sağlığ koruyucu ve geliştirici nitelikteki sanayi yan ürünlerinin değerlendirilmesi, hayvansal protein ihtiyacının karşılanabilmesi ve çevre sağlı̆̆ bakımından büyük öneme sahiptir (Kurt ve Gülümser, 1987; Metin, 1998).

PAS; organik asit ya da peynir mayası kullanılarak pihtılaştırılan sütten elde edilen pihtının, peynir üretiminde kullanılmak üzere ayrllmasından sonra geriye kalan yeşilimsi sarı renkteki sıvıya verilen isimdir (Yerlikaya vd., 2010). Peynir üretiminde yaklassık olarak $6 \mathrm{~kg}$ sütten $1 \mathrm{~kg}$ peynir elde edilirken $5 \mathrm{~kg}$ PAS açığa çıkmaktadır. Her ne kadar 2017 yllı TÜİK verilerine göre Türkiye'de yaklaşı 517 bin ton PAS elde edildiği rapor edilmiş olsa da, yine TÜİK verilerine göre Türkiye'nin yaklaşı peynir üretim miktarı olan 690 bin ton dikkate alındığında ülkemizde yaklaşık 3.5 milyon ton PAS açığa çıktığ hesap edilebilmektedir (Anonim, 2017).

PAS, insan gidası olarak doğrudan kullanılmamaktadır (Metin, 1998). Bu nedenle, patojenik mikroorganizmaların tamamını yok edecek sıcaklık ve sürede isıl işlem uygulanarak pastörize edilen PAS (Harding, 1999); peynir altı suyu konsantresi, peynir alt1 suyu tozu, yoğurt, tereyağı, lor peyniri, içecek, tarhana, yenilebilir film ya da organik asit gibi çeşitli ürünlere işlenerek değerlendirilebilmektedir. Ancak Türkiye'de maliyetinin yüksek, kullanılan miktarların ise çok az olması gibi nedenlerle PAS'in çok az bir bölümü bu şekilde değerlendirilirken geri kalan önemli bir kısmı ise atık olarak doğrudan doğaya salınmaktadır
(Bodnár vd., 2007; Koca ve Tarakç1, 1997; Kurt ve Gülümser, 1987).

PAS; içeriğindeki laktoz (\%5), serum proteinleri $(\% 0.7)$, mineraller ( $\% 0.2)$ ve vitaminler (B grubu) gibi besin bileşenleri nedeni ile mikroorganizmalar için iyi bir besin kaynağıdır. PAS'ın akarsulara ve denizlere boşaltılması sonucu suyun organik madde içeriği artmakta ve mikroorganizmalar bu ortamda aşırı çoğalarak sudaki çözünmüş oksijeni kullanmaktadırlar. Bu durum sudaki oksijen seviyesinin düşmesine sebep olurken su ekosisteminde bulunan doğal popülasyona da zarar vermektedir (Kurt ve Gülümser, 1987; Üçüncü, 2004). Bu nedenlerle peynir sanayinin yan ürünü olan PAS, önemli bir çevre kirleticisi konumuna gelmektedir (Gonçalves Cibely vd., 2017; Gamba vd., 2016; Paul vd., 2016). Önemli besin bileşenlerini yapisında bulunduran PAS'ın atık olarak doğaya salınması yerine (Yerlikaya vd., 2010; Paul vd., 2016), tahıla dayalı beslenme alışkanlığı olan ülkelerde fazlaca tüketilen, ucuz, doyurucu, fakat esansiyel aminoasitler açısından fakir olan ekmek ve diğer hububat mamullerinin zenginleştirilmesi amacıyla kullanılması bu ürüne alternatif bir kullanım imkanı sunmaktadır.

Ekmek temel olarak; un, tuz, maya ve suyun belli oranlarda karıştırılması ile oluşturulan hamurun şekillendirilmesi, fermantasyona bırakılması ve pişirilmesiyle elde edilen temel bir gida maddesidir (Salazar vd., 2017; Paul vd., 2016; Demir vd., 2009). Yaklaş1k $100 \mathrm{~kg}$ undan $60 \mathrm{~L}$ kadar su kullanılarak $140 \mathrm{~kg}$ kadar ekmek üretilmektedir. Türkiye'de günde kişi başı ortalama ekmek tüketimi 400 g kadardır (Demir vd., 2009). Dolayısıyla, Türkiye'de günde yaklaşık 32 bin ton, yllda ise 12 milyon ton kadar ekmek tüketilmektedir. Yıllık bu kadar ekmeğin üretiminde ise bileşen olarak yaklaşık 5 milyon ton su kullanımı gerekmektedir. Yıllık ekmek üretimi için gerekli olan su miktarının yaklaşık yarısı PAS ile karşılanabilir. Böylelikle çevreye salındığı için atığa dönüssen PAS ortadan kaldırılırken, ekmeğin besin içeriğinin zenginleştirilmesi de mümkün olmaktadır (Salazar vd., 2017).

PAS proteinleri kullanılarak mayalı ve mayasız hamurdan ekmek üretiminin gerçekleştirildiği bir 
çalışmada, pişirme işlemi sonucunda PAS proteinlerinin antioksidan potansiyelleri ve elde edilen ekmeğin tekstürel özellikleri araştırılmış ve sertlik ve çiğnenebilirlik değerlerinin PAS proteini ile artış gösterdiği belirlenmiştir (Gonçalves Cibely vd., 2017). Kopeć vd. (2014) ise ekşi maya ve PAS proteinleri ilavesiyle üretilen tam buğday ekmeğinin bazı kimyasal özelliklerini (protein, yağ, karbonhidrat ve lif miktarları) ve bu ekmeğin içeriğindeki proteinlerin ve minerallerin deney hayvanları üzerindeki biyolojik değerini incelemiş ve eklenen PAS proteinleri ile ekmekteki düşük kaliteli proteinin kalitesinin arttığını belirlemiştir. Konsantre PAS ilavesiyle besinsel olarak zenginleştirilmiş ekmek üretiminin gerçekleştirildiği bir çalışmada, çok tahıllı hamur ve bu hamurdan kabul edilebilir kalitede bir ekmek üretilmesi için su yerine $\% 15$ oranında konsantre PAS kullanılabileceği belirtilmiştir (Paul vd., 2016). Divya ve Rao (2010) da Hindistan'a özgü bir peynirin PAS'ını \%15 ve \%26 kuru madde içeriklerine konsantre ettikten sonra su ikamesi olarak ekmek üretiminde kullanımını araştırmışlardır. Kinoa unu ve PAS ilavesinin ekmek özellikleri üzerine etkilerinin araştırıldığ bir çalışmada, ekmek üretiminde kullanılan suyun tamamı yerine PAS kullanılabileceği sonucuna varılmıştır. Ancak bu çalışmada PAS ve kinoa ununun ekmek üzerindeki ortak etkileri incelenmiş ve sadece PAS kullanımıyla meydana gelen değişimler tespit edilmemiştir (Salazar vd., 2017). Bilgin vd. (2006) ise, pastörize PAS ve yayık altı suyunu ekmek üretiminde su ikamesi olarak kullanmıs ve $\% 0, \% 50$ ve $\% 100$ oranında PAS ve yayık altı suyu kullanımının hamur ve ekmek kalitesi üzerindeki etkisini inceleyerek PAS kullanımıyla ekmek içinde zamanla meydana gelen sertleşmenin geciktiğini ve mineral madde miktarında artış olduğunu belirlemişlerdir.

Literatürde PAS ile yapılan çalşmalar incelendiğinde genel olarak firnn ürünleri içerisine PAS tozu, PAS proteinleri ve PAS konsantrelerinin ilave edildiği, pastörize PAS kullanımının ise firın ürünlerinde, özellikle de tam buğday unuyla üretilen ürünlerde, sinırlı olduğu görülmektedir. Ayrıca bu ürünlerin ilave edilmesiyle elde edilen nihai ürünlerin HMF içerikleri üzerinde herhangi bir çalışma da yapılmamıştır. $\mathrm{Bu}$ çalışmada; peynir üretimi sırasında çok yüksek miktarlarda ortaya çıktı̆̆1 için, zengin besin içeriğine rağmen ekonomik olarak değerlendirilemeyip önemli bir çevre kirleticisine dönüşen PAS'ın; pastörizasyon ile dayaniminin arttırilmasi, beyaz ekmek ve tam buğday unu ekmeklerinin üretiminde su ikamesi olarak kullanılma imkânlarının ve bu ekmeklerin HMF içerikleri üzerine etkisinin araştırılması amaçlanmıştır.

\section{MATERYAL VE METOT \\ Materyal}

Araştırma kapsamında gerçekleştirilen ekmek üretiminde; beyaz (ekmeklik) un ve katkısız tam buğday unu, rafine tuz, ticari pres yaş maya ve içilebilir nitelikte su kullanılmıştır. Araştırmada kullanılan PAS; \%0.88 protein, \%0.08 yağ ve \%6.05 yağsız kuru madde içeriğinde, pastörize sütten üretilen beyaz peynir altı suyu olarak bir peynir fabrikasindan (Ekici Peynir, Antalya) temin edilmiştir. Analizler için gerekli olan kimyasal maddeler analizin niteliğine göre analitik, kromatografik ve mikrobiyolojik saflıklarda kullanılmıştır.

\section{Araştırma planı ve istatistiksel analiz}

Araştırmada iki farklı un (beyaz un ve tam buğday unu) kullanilarak hazırlanan ekmek formülasyonlarına 5 farklı oranda pastörize PAS (eklenmesi gereken toplam suyun $\% 0, \% 25, \% 50$, $\% 75$ ve $\% 100$ 'ü) ilave edilerek $2 \times 5$ deneme desenine göre 10 farklı ekmek üretimi gerçekleştirilmiştir. Araştırma 2 tekerrürlü olarak gerçekleştirilmiş, analizler ise paralelli olarak yapılmıstır. Laboratuvar analizlerine dayalı parametrelerin istatistiksel hesaplamaları SAS istatistik programı (SAS Institute Inc., Cary, NC, ABD) kullanilarak, verilere varyans analizi (ANOVA) ve önemli bulunan parametrelere Duncan Çoklu Karşılaştırma Testi $(P<0.05)$ uygulanarak gerçekleştirilmiştir. Duyusal analiz sonuçlarının istatistiksel hesaplamaları ise SPSS istatistik programı (IBM SPSS Statistics, ABD) kullanılarak Kruskal Wallis testi ile gerçekleştirilmiştir. Değerler ortalama \pm standart hata olarak verilmiştir. 


\section{Peynir altı suyunun pastörizasyonu}

Araştırma kapsamında temin edilen PAS'ta var olan patojen mikroorganizmaların tamamen yok edilmesini sağlayabilmek için, bu PAS’a 5 farklı sicaklıkta $\left(55,60,65,70\right.$ ve $\left.75^{\circ} \mathrm{C}\right) 4$ farklı süre $(5$, 10,15 ve 20 dakika) boyunca 1 sil işlem uygulanarak denemeler yapılmıştır. Denemelerde; farklı tüplere alınan PAS, belirtilen sıcaklık ve süre koşullarında 1sıl işleme tabi tutulmuş ve bu tüpler 8 gün süreyle $+4^{\circ} \mathrm{C}$ 'de depolanarak, depolamanın her gününde mikrobiyolojik analizler yapılmıştır. Araştırmada PAS’ın pastörize olmasını sağlayan en düşük sicaklik ve süre kombinasyonunun $75^{\circ} \mathrm{C}$ 'de 15 dakika 1 sıl işlem uygulaması olduğu tespit edilmiş ve bu şartlarda pastörize edilen PAS ekmek üretiminde kullanılmıştır.

\section{Mikrobiyolojik analizler}

Isıl işlem uygulanan ve uygulanmayan PAS'in toplam maya/küf sayısı APHA (1976)'ya, toplam mezofilik aerobik bakteri sayıs1 ISO (2001)'ya, toplam koliform say1s1 TSE (1992)'ye, toplam Escherichia coli say1s1 Anonim (1999)'e ve toplam Enterobacteriaceae say1sı ise Halkman (2005)'a göre belirlenmiştir.

\section{Un analizleri}

Un örneklerinin kuru madde miktarı ICC (1976) Metot No: 110/1'e, toplam kül miktarı ICC (1990) Metot No: 104/1'e ve protein miktar1 ise ICC (1994) Metot No: 105/2'ye göre belirlenmiştir. Örneklerin yaş gluten miktarı ICC (1994) Metot No: 137/1'e göre ve kuru gluten miktarı ise yaş glutenin Glutork 2020 (Perten Instruments Co., Ltd., İsveç) cihazında 5 dakika kurutulup desikatörde soğutularak tartılması ile belirlenmiştir (Özkaya ve Özkaya, 2005). Sedimantasyon değerleri ICC (1994) Metot No: 116/1'e ve düşme sayısı değerleri ise ICC (1995) Metot No: 107/1'e göre belirlenmiştir. Unların farinograf analizi ICC (1992) Metot No: 115/1'e göre, ekstensograf analizi ise ICC (1992) Metot No: 114/1'e göre farkl1 oranlarda PAS kullanılarak gerçekleştirilmiştir. Farinograf analizi ile unun su absorpsiyonu (\%), ekstensograf analizi ile ise 45., 90. ve 135. dakikalardaki enerji değeri $\left(\mathrm{A}, \mathrm{cm}^{2}\right.$ ), hamurun uzama kabiliyeti ( $\left.\mathrm{mm}\right)$ ve hamurun uzamaya karşı gösterdiği max direnç $\left(\mathrm{R}_{\mathrm{m}}, \mathrm{BU}\right)$ belirlenmiştir. Ekstensograf analizine ait sonuçlar için 45., 90. ve 135. dakikalardaki değerlerin ortalamalanı üzerinden değerlendirmeler yapılmıştır.

\section{Ekmek üretimi}

Un (2000 g), maya (40 g), tuz (40 g) ve ICC (1992) Metot No: 115/1'e göre farinograf analizi ile belirlenen miktarda su ve/veya PAS ( $\% 0, \% 25$, $\% 50, \% 75$ ve \%100’ü), tekniğine uygun olarak hamur yoğurma makinesinde (Ayhandemir, Konya, Türkiye) karıştırılıp, 20 dakika yoğurularak hamur oluşturulmuştur (Elgün ve Ertugay, 2002). Yoğurulan hamur 30 dakika kitle fermantasyonuna birakılmış ve yaklaşık $100 \mathrm{~g}$ yuvarlak ekmek (roll ekmek) üretmek üzere bu hamurdan $115 \mathrm{~g}$ kesilmiştir. Elle küresel şekil verilen hamurlar daha sonra 10 dakika dinlendirilmiştir. Süre sonunda hamurlar elle yuvarlanıp tekrar küresel şekil verilerek ekmek tavasına yerleştirilmiştir. Tavaya alınan hamurlar $\% 85$ nisbi nem içeriğine sahip $32^{\circ} \mathrm{C}$ sicaklıktaki fermantasyon kabininde 60 dakika daha fermantasyona birakılmıştır. Fermantasyon sonunda pişirme sicaklığındaki $\left(250^{\circ} \mathrm{C}\right)$ elektrikli firına (Fimak EKF60, Konya) alınan hamurlar, ön denemelerle 40 dakika olarak belirlenen sürede (ekmek nem içeriğinin <\%40 olmasını sağlayan süre) pişirilmiştir.

Üretilen ekmeklerin fiziksel analizleri üretimden 2 saat sonra, duyusal analizi ise 3 saat sonra gerçekleştirilmiştir. Kimyasal analizler ise; 2 saatlik dinlenme periyodu sonunda kabuk ve iç olarak ayrilan ve analiz edilinceye kadar $-18^{\circ} \mathrm{C}$ 'de kilitli plastik ambalajlar içerisinde muhafaza edilen örnekler kullanılarak yapılmıştır.

\section{Ekmeklerde yapılan fiziksel analizler}

Spesifik hacim, ekmeklerin hacim değerinin ekmek ağırlığına bölünmesi ile $\mathrm{cm}^{3} / \mathrm{g}$ olarak belirlenmiştir. Ekmek ağırlıkları ekmeklerin firından alındiktan 2 saat sonra tartilmasi ile; ekmek hacimleri ise kolza tohumuyla dolu ölçme kabından taşan kolza miktarının $\mathrm{cm}^{3}$ cinsinden belirlenmesi ile tespit edilmiştir (Elgün vd., 2002).

Ekmeklerin renk değerleri, renk ölçer (Minolta, Kyoto, Japonya) kullanilarak $L^{*}$ (siyahlık beyazlık), $a^{*}$ (kırmızılık - yeşillik) ve $b^{*}$ (sarılık - 
mavilik) değerlerinin tespit edilmesiyle belirlenmiştir (Clerici vd., 2009). Ekmeklerin kabuk rengi üst ve alt kabuklarının, iç rengi ise ekmek dilimlerinin üçer farklı noktasından yapılan ölçümlerin ortalamaları alınarak belirlenmiştir.

Ekmeklerin sertlik, kirllganlik, elastikiyet, çiğnenebilirlik ve esneklik özellikleri tekstür profil analiz (TPA) cihazı (TA, Stable Microsystems, Surrey, İngiltere) kullanılarak, $3 \mathrm{~cm}$ kalınlığında kesilen ekmek dilimleri üzerinden belirlenmiştir. Analiz 100 mm'lik silindirik prop ve 5 kg'llk yük hücresi ile gerçekleştirilmiştir. Test öncesi hız 2 $\mathrm{mm} / \mathrm{s}$, test hiz1 $3 \mathrm{~mm} / \mathrm{s}$, test sonras 1 hı $3 \mathrm{~mm} / \mathrm{s}$, bekleme süresi $5 \mathrm{~s}$, tetik kuvveti $10 \mathrm{~g}$ ve uzaklık ise $\% 70$ deformasyon sağlayan mesafe olacak şekilde ayarlanmıştır (Gåmbaro vd., 2002).

\section{Ekmeklerde yapılan kimyasal analizler}

Örneklerin kuru madde içerikleri; sabit ağırlığa getirilmiş ve darası alınmış petri kaplarına yaklaşık $10 \mathrm{~g}$ örnek tartılip, bu örneklerin $105^{\circ} \mathrm{C}$ 'de sabit ağırlı̆ga gelinceye kadar kurutulmasıyla, ağırlıkta meydana gelen değişim üzerinden belirlenmiştir (Elgün vd., 2002).

Ekmek örneklerinin hidroksimetil furfural (HMF) içeriği, Fallico vd. (2004)'nin metodu modifiye edilerek kromatografik olarak belirlenmiştir. Bu amaçla, $0.5 \mathrm{~g}$ örnek üzerine $5 \mathrm{~mL}$ deiyonize su eklenmiş ve tüp içeriği 1 dakika süreyle karıştırıldıktan sonra örnek çözeltisi üzerine 0.25 $\mathrm{mL}$ Carrez I ve Carrez II çözeltileri ilave edilmiştir. Elde edilen karışım santrifüj edilerek berrak olan süpernatant kısmı başka bir tüpe aktarılmış ve hacmi deiyonize su ile $10 \mathrm{~mL}$ 'ye tamamlanmıştır. Kromatografi işlemi; $\mathrm{C}_{18}(250 \mathrm{x}$ $4 \mathrm{~mm}, 5 \mu \mathrm{m}$ ) kolon ve DAD dedektör kullanılarak $280 \mathrm{~nm}$ dalga boyunda gerçekleştirilmiştir. Bunun için $0.45 \mu \mathrm{m}$ filtreden geçirilen örnekten $20 \mu \mathrm{L}$ alınarak HPLC sistemine enjekte edilmiş, hareketli faz olarak $1 \mathrm{~mL} / \mathrm{dak}$ akış hızına sahip asetonitril:su (5:1) kullanılmış ve kolon firını sıcaklığ $32^{\circ} \mathrm{C}$ 'ye ayarlanmıştır. Örneklerdeki HMF miktarı harici standart metodu kullanılarak hesaplanmıştır.

\section{Ekmeklerin duyusal analizi}

Ekmeklerin duyusal değerlendirmesi, duyusal değerlendirme hakkında bilgi sahibi 10 panelist tarafından diş (hacim, kabuk rengi, şekil simetrisi, kabuk ve kenar özelliği) ve iç (gözenek yapısı, tat, çiğneme ve tekstür) özellikler dikkate alınarak 5 puanlık hedonik skalaya göre (1: hiç beğenmedim; 5: çok beğendim) yapılmıştır (Elgün ve Ertugay, 2002).

\section{BULGULAR VE TARTIŞMA}

Pastörizasyon öncesi ve sonrasinda PAS'ın toplam mikroorganizma yükü

Çalışma kapsamında; pastörizasyon için $75^{\circ} \mathrm{C}$ 'de 15 dakika isıl işleme tabi tutulan PAS'in mikrobiyolojik yükü 8 gün boyunca takip edilmiştir. PAS içerisinde pastörizasyon öncesinde $1 \mathrm{kob} / \mathrm{mL}$ koliform, $6 \mathrm{kob} / \mathrm{mL}$ Enterobacteriaceae ve $>10^{7} \mathrm{kob} / \mathrm{mL}$ toplam canl bulunduğu, pastörizasyon sonrasında ise koliform grubu bakteriler ve Enterobacteriaceae familyasina ait bakterilerin tamamı yok edilirken, toplam canlı miktarının $8.1 \times 10^{2} \mathrm{kob} / \mathrm{mL}$ ye düştüğü tespit edilmiştir. Takip edilen 8 gün boyunca toplam canlı sayısinda dalgalanmalar meydana gelse de ortamda ortalama $6.6 \times 10^{2} \mathrm{kob} / \mathrm{mL}$ canlı bulunduğu belirlenmiştir. Isıl işlem, temel amac1 patojenik ve bozulmaya neden olan mikroorganizmaları etkisiz hale getirmek olan ve gıda güvenliğini sağlamak için uygulanması gereken bir işlemdir (Ma vd., 2019; Wang vd., 2018). Yaygın olarak uygulanan ssıl işlemler ultra yüksek sicaklik (UHT) ve pastörizasyondur. Koliform grubu bakteriler çevresel kaynaklardan gıda ürünlerine bulaşmaktadır ve pastörizasyon sonras1 kontaminasyonu gösteren indikatör mikroorganizmalar arasında yer almaktadır. Kang vd. (2018) yaptıkları çalışmada, pastörizasyon sonrasi sütteki koliform grubu bakterilerin ve Enterobacteriaceae üyesi bir bakteri olan Escherichia coli nin tamamen yok edildiğini, toplam mezofilik aerobik bakterilerin ise neredeyse yarısının öldügünü tespit etmişlerdir.

Ekmek üretiminde kullanılan unların kimyasal ve teknolojik özellikleri

Ekmek üretiminde kullanılan unların kimyasal özelliklerinden nem, kül ve protein miktarları beyaz un için sırasiyla \%13.00, 0.92 ve 11.30 olarak; tam buğday unu için ise sirasiyla $\% 11.20$, 1.65 ve 13.55 olarak tespit edilmiştir. Bu unların teknolojik özelliklerinden yaş gluten ile kuru gluten miktarları beyaz un ve tam buğday unu için 
sirasiyla \%28.55-9.31 ve \%22.45-7.53 olarak belirlenmiştir. Sedimantasyon ve düşme sayıs1 değerleri ise beyaz un için sirasıyla $20.65 \mathrm{~mL}$ ve 255.43 s olarak tespit edilirken, tam buğday unu için sırasıyla $16.95 \mathrm{~mL}$ ve $255.31 \mathrm{~s}$ olarak tespit edilmiştir.

Araştırmada kullanılan beyaz ve tam buğday unlarının genel kimyasal özelliklerinin Türk Gıda Kodeksi Buğday Unu (2013/9) Tebliği'ne (Anonim, 2013) ve teknolojik özelliklerinin ilgili ekmeği üretmeye genel olarak uygun olduğu belirlenmiştir (Elgün vd., 2002). Türk Gıda Kodeksi Buğday Unu Tebliği (Anonim, 2013)'ne göre beyaz buğday ununun nem içeriği en çok $\% 14.5$, kül içeriği en çok $\% 0.8$, protein miktarı en az $\% 10.5$, sedimentasyon değeri en az $26 \mathrm{~mL}$ ve düşme sayısı en az $250 \mathrm{~s}$ olmalıdır. Tam buğday unu için ise sedimentasyon ve düşme sayisı değerleri aranmazken, nem içeriği en çok \%14.5, kül içeriği en az $\% 1.2$ ve protein miktarı en az $\% 11$ olmalıdır. Ekmeklik beyaz un için yaş gluten miktarının en az \%27 olması istenmektedir. Tam buğday ununun sedimantasyon ve gluten değerlerinin ekmeklik beyaz undan düşük olmasının, kepek içeriğinin yüksek olmasından kaynaklandığı değerlendirilmiştir.

Un çeşidi ve farklı oranlardaki PAS kullanımına ait temel farinograf ve ekstensograf özellikleri ise Çizelge 1'de verilmiştir. Un çeşidi ve farklı oranlarda PAS kullanımınin; su absorpsiyonu ve $\mathrm{R}_{\mathrm{m}}$ değeri üzerine önemli $(P>0.05)$ bir etkide bulunmadığ 1 , ancak uzama kabiliyeti ve enerji değerleri üzerine önemli $(P<0.05 ; P<0.01)$ bir etkisinin olduğu tespit edilmiştir. Ekstensografta test süresine bağlı oluşarak kurve taban uzunluğunu gösteren hamurun uzama kabiliyetinin ve kurve altında kalan alandan hesaplanarak hamurun ekmeğe dönüşme kabiliyeti hakkında bilgi veren enerji değerinin beyaz unda ve PAS ilavesinde daha yüksek olduğu belirlenmiştir. $\mathrm{Bu}$ durumun beyaz unda gluten içeriğinin yüksek olmasından ve PAS ilavesinin ise ilave protein ile gluten içeriğini desteklemesinden kaynaklanabileceği değerlendirilmiştir.

Çizelge 1. Unların farklı PAS oranlarındaki temel farinograf ve ekstensograf özellikleri Table 1. Base farinograph and extensograph characteristics of flour in different $P A S$ ratios

\begin{tabular}{|c|c|c|c|c|}
\hline \multirow{2}{*}{$\begin{array}{l}\text { Un çeşidi } \\
\text { Flour type }\end{array}$} & $\begin{array}{l}\text { Farinograf } \\
\text { Farinograph } \\
\end{array}$ & \multicolumn{3}{|c|}{$\begin{array}{c}\text { Ekstensograf } \\
\text { Extensograph }\end{array}$} \\
\hline & $\begin{array}{c}\text { Su absorpsiyonu } \\
\text { Water absorption } \\
(\%)\end{array}$ & $\begin{array}{l}\text { Enerji } \\
\text { Energy } \\
\left(\mathrm{cm}^{2}\right)\end{array}$ & $\begin{array}{c}\text { Uzama kabiliyeti } \\
\text { Extensibility } \\
(\mathrm{mm})\end{array}$ & $\begin{array}{c}\text { Max direnç } \\
\text { Max resistance } \\
\left(\mathrm{R}_{\mathrm{m}}, \mathrm{BU}\right)\end{array}$ \\
\hline $\begin{array}{l}\mathrm{BU} \\
W F\end{array}$ & $61.06^{a} \pm 0.46$ & $62.73^{a} \pm 2.06$ & $103.07 \mathrm{a} \pm 4.37$ & $486.47^{a} \pm 26.16$ \\
\hline $\begin{array}{l}\text { TBU } \\
W W F\end{array}$ & $61.70^{a} \pm 0.55$ & $52.73^{\mathrm{b}} \pm 2.07$ & $76.20^{\mathrm{b}} \pm 2.38$ & $529.20^{a} \pm 19.46$ \\
\hline $\begin{array}{l}\text { Önem } \\
\text { Significance }\end{array}$ & - & ** & ** & - \\
\hline $\begin{array}{l}\text { PAS oran1 } \\
\text { Whey ratio }\end{array}$ & & & & \\
\hline$\% 0$ & $60.40^{a} \pm 0.91$ & $47.67 \mathrm{~b} \pm 2.33$ & $76.33^{b} \pm 5.94$ & $495.17 a \pm 34.20$ \\
\hline$\% 25$ & $60.55^{a} \pm 0.79$ & $62.50^{a} \pm 3.28$ & $92.50^{a} \pm 9.23$ & $540.00^{a} \pm 36.20$ \\
\hline$\% 50$ & $62.10^{a} \pm 0.70$ & $56.83^{a} \pm 3.11$ & $92.67 \mathrm{a} \pm 7.93$ & $481.50^{a} \pm 37.79$ \\
\hline$\% 75$ & $61.35^{\mathrm{a}} \pm 0.70$ & $60.67 \pm \pm 5.17$ & $93.00^{a} \pm 8.86$ & $508.50^{a} \pm 41.24$ \\
\hline$\% 100$ & $62.50^{\mathrm{a}} \pm 0.70$ & $61.00^{a} \pm 1.83$ & $93.67 \mathrm{a} \pm 6.89$ & $514.00^{a} \pm 43.64$ \\
\hline $\begin{array}{l}\text { Önem } \\
\text { Significance }\end{array}$ & - & $* *$ & * & - \\
\hline
\end{tabular}

BU: Beyaz un, TBU: Tam buğday unu

Önem: ** $P \leq 0.01, * 0.01<P \leq 0.05,-P>0.05$ (önemsiz)

WF: White flour, WWF: Whole wheat flour

Significance: $* * P \leq 0.01, * 0.01<P \leq 0.05,-P>0.05$ (insignificant) 


\section{Üretilen ekmeklerin bazı fiziksel özellikleri}

Farklı çeşit un ve farklı oranlarda PAS kullanılarak üretilen ekmeklerin renk özellikleri Çizelge 2'de, TPA özellikleri Çizelge 3'te ve spesifik hacim değerleri Çizelge 4'te verilmiştir. Ekmeklerin spesifik hacim değeri üzerine un çeşidinin $(P$ $<0.01)$ ve PAS oraninin $(P<0.05)$ istatistiksel olarak önemli bir etkisinin olduğu tespit edilmiştir. Beyaz un ve tam buğday unu ile üretilen ekmeklerin spesifik hacim ortalamaları sirasiyla 2.07 ve $2.48 \mathrm{~cm}^{3} / \mathrm{g}$ olarak belirlenmiş ve PAS ilavesi ekmeklerin spesifik hacim değerini kontrol örneğine (\%0 PAS) göre arttırmıştır. Bilgin vd. (2006) çalışmalarında, ekmeklerin spesifik hacim değerlerinin pastörize PAS kullanımından önemli şekilde etkilenmediğini belirlemişlerdir. Isıl işlem görmemiş PAS proteinleri buğday unundaki glutene etki ederek ekmek üzerinde olumsuz etkiler meydana getirmektedir. Ancak PAS 1sil işlem gördügünde proteinlerin doğal, sık1 şekilde katlanmıs ve kararlı yapısı, denatürasyon sonucu çözünürlüğü azalmış ve katlanmamış bir yapıya dönüşmektedir (Guemes-Vera vd., 2014). Bu dönüşümle birlikte ekmek özelliklerinin geliştiği ve spesifik hacim değerinin arttığ değerlendirilmiştir.

Un çeşidinin ekmeklerin kabuk ve iç rengini önemli düzeyde $(P<0.05 ; P<0.01)$ etkilediği, PAS kullanımının ise yalnızca ekmeklerin kabuk rengi üzerinde önemli $(P<0.05 ; P<0.01)$ bir etkisinin olduğu tespit edilmiştir. Tam buğday unuyla üretilen ekmeklerin kabuk ve iç renkleri, buğday kepeğinin kendine has renginden dolayı daha koyu olarak belirlenmiştir. Üretimde kullanılan PAS oranının artmasiyla ekmeklerin kabuklarına ait $L^{*}$ ve $b^{*}$ renk değerleri azalmıştır. Artan PAS oranıyla birlikte indirgen şeker olan laktozun ve azotlu madde içeriğinin de artmasıly ekmek kabuğunda gerçekleşen Maillard reaksiyonuna bağlı olarak rengin koyulaştı̆̆ değerlendirilmiştir (Paul vd., 2016; Elgün, 1986). Yapılan bir çalışmada, ekmek formülasyonundaki şeker içeriğinin arttırlmasıly ekmek rengine ait $L^{*}$ değeri azalırken, $a^{*}$ değerinin artış gösterdiği rapor edilmiştir (Doğan ve Yıldız, 2009). Süt sanayisi yan ürünlerinin ekmek formülasyonuna artan oranlarda ilave edilmesiyle benzer şekilde ekmek rengine ait $L^{*}$ değerinde azalma meydana geldiği bildirilmiştir (Demir vd., 2009; Guemes-Vera vd., 2014).

Un çeşidinin ekmeklerin tüm TPA özelliklerini önemli bir düzeyde $(P<0.05 ; P<0.01)$ etkilediği, kullanılan PAS oranının ise yalnızca ekmeklerin sertlik ve elastikiyet parametreleri üzerinde önemli $(P<0.05)$ bir etki gösterdiği belirlenmiştir. Tam buğday unu kullanılarak üretilen ekmeklerin sertlik, kohezif yapısskanlık (iç yapışkanlık), çiğnenebilirlik ve esneklik değerlerinin oldukça yüksek, elastikiyet değerinin ise beyaz un ile üretilen ekmeklere göre daha düşük olduğu tespit edilmiştir. $\mathrm{Bu}$ durumun ekmek üretiminde kullanılan tam buğday ununun kepek içeriğinden kaynaklandığı düşünülmektedir. PAS oranının artmastyla birlikte sertlik değerinin azalması, PAS ilavesinin ekmeği daha yumuşak bir hale getirdiği ve yutulmasını kolaylaştırdığı şeklinde değerlendirilmiştir. PAS proteinlerinin ekmek hamuruna dâhil edilmesi su emilimini arttırmakta ve sonuç olarak ekmek dokusunu iyileştirmektedir. Ayrıca PAS proteinlerinin denatürasyon derecesinin artmasi da ekmek üretim sürecinin işlevselliğini arttırıc1 etki yapmaktadır (Guemes-Vera vd., 2014).

\section{Üretilen ekmeklerin bazı kimyasal özellikleri}

Farklı çeşit un ve farklı oranda PAS kullanılarak üretilen ekmeklerin bazı kimyasal özellikleri Çizelge 4'te verilmiştir. Ekmeklerin kuru madde içerikleri üzerine un çeşidi $(P<0.01)$ ve PAS oranının $(P<0.05)$ önemli bir etkisinin olduğu tespit edilmiştir. Ekmeklere ilave edilen PAS oranı arttıkça (\%25-100) ekmeklerin kuru madde içeriklerinde de artış meydana gelmiştir. Bu durumun PAS'ın kuru madde içeriğinin yüksek olmasından kaynaklandığı değerlendirilmiştir. Salazar vd. (2017) tarafindan yapılan bir çalışmada da benzer şekilde ekmeklere ilave edilen PAS oranının artmasiyla ekmeklerin kuru madde içerikleri artmıştır. Rafine edilmiş beyaz buğday unu ile karşılaştırıldığında tam buğday unu; vitamin, mineral, diyet lif ve diğer önemli gida bileşenlerince daha zengindir (Tebben vd., 2018). $\mathrm{Bu}$ nedenle, tam buğday unundan elde edilen ekmeklerin kuru madde içeriklerinin daha yüksek olduğu düşünülmektedir. 
Çizelge 2. Üretilen ekmeklerin renk özellikleri Table 2. Colour properties of produced bread

\begin{tabular}{|c|c|c|c|}
\hline \multirow{2}{*}{$\begin{array}{l}\text { Un çeşidi } \\
\text { Flour type }\end{array}$} & \multicolumn{3}{|c|}{$\begin{array}{l}\text { Kabuk rengi } \\
\text { Colour of crust }\end{array}$} \\
\hline & $L^{*}$ & $a^{*}$ & $b^{*}$ \\
\hline $\begin{array}{l}\mathrm{BU} \\
W F\end{array}$ & $55.91^{\mathrm{a}} \pm 1.51$ & $8.37^{b} \pm 0.40$ & $33.06^{a} \pm 0.70$ \\
\hline $\begin{array}{l}\text { TBU } \\
W W F\end{array}$ & $45.32^{\mathrm{b}} \pm 0.79$ & $9.57^{a} \pm 0.18$ & $28.04^{b} \pm 0.54$ \\
\hline $\begin{array}{l}\text { Önem } \\
\text { Significance }\end{array}$ & $* *$ & $*$ & $* *$ \\
\hline \multicolumn{4}{|l|}{$\begin{array}{l}\text { PAS orani } \\
\text { Whey ratio }\end{array}$} \\
\hline$\% 0$ & $54.81^{\mathrm{a}} \pm 3.83$ & $8.12^{\mathrm{a}} \pm 1.01$ & $32.69^{a} \pm 1.38$ \\
\hline$\% 25$ & $52.77 \mathrm{ab} \pm 4.28$ & $8.77^{a} \pm 0.57$ & $31.94^{\mathrm{ab}} \pm 1.99$ \\
\hline$\% 50$ & $49.42^{\mathrm{bc}} \pm 3.53$ & $9.50^{\mathrm{a}} \pm 0.47$ & $30.31^{b c} \pm 1.31$ \\
\hline$\% 75$ & $48.31^{b c} \pm 3.07$ & $9.31^{\mathrm{a}} \pm 0.15$ & $29.54^{\mathrm{cd}} \pm 1.91$ \\
\hline$\% 100$ & $47.75^{\mathrm{c}} \pm 1.08$ & $9.15^{\mathrm{a}} \pm 0.19$ & $28.26^{\mathrm{d}} \pm 0.91$ \\
\hline $\begin{array}{l}\text { Önem } \\
\text { Significance }\end{array}$ & $*$ & - & $* *$ \\
\hline \multirow{2}{*}{$\begin{array}{l}\text { Un çeşidi } \\
\text { Flour type }\end{array}$} & & $\begin{array}{l}\text { İç rengi } \\
\text { colour of crumb }\end{array}$ & \\
\hline & $L^{*}$ & $a^{*}$ & $b^{*}$ \\
\hline $\begin{array}{l}\mathrm{BU} \\
W F\end{array}$ & $77.62^{\mathrm{a}} \pm 0.50$ & $-6.04^{b} \pm 0.06$ & $23.84^{b} \pm 0.20$ \\
\hline $\begin{array}{l}\text { TBU } \\
W W F\end{array}$ & $57.79^{\mathrm{b}} \pm 0.63$ & $3.06^{\mathrm{a}} \pm 0.07$ & $24.70^{a} \pm 0.17$ \\
\hline $\begin{array}{l}\text { Önem } \\
\text { Significance }\end{array}$ & $* *$ & $* *$ & $* *$ \\
\hline \multicolumn{4}{|l|}{$\begin{array}{l}\text { PAS oran1 } \\
\text { Whey ratio }\end{array}$} \\
\hline$\% 0$ & $66.61^{a} \pm 5.66$ & $-1.42^{\mathrm{a}} \pm 2.56$ & $23.96^{\mathrm{a}} \pm 0.24$ \\
\hline$\% 25$ & $67.89^{a} \pm 5.07$ & $-1.41^{a} \pm 2.61$ & $23.92^{\mathrm{a}} \pm 0.43$ \\
\hline$\% 50$ & $67.50^{a} \pm 6.57$ & $-1.52^{\mathrm{a}} \pm 2.71$ & $24.08^{a} \pm 0.35$ \\
\hline$\% 75$ & $68.38^{a} \pm 5.45$ & $-1.46^{a} \pm 2.63$ & $24.75^{a} \pm 0.39$ \\
\hline$\% 100$ & $68.16^{\mathrm{a}} \pm 6.12$ & $-1.65^{a} \pm 2.65$ & $24.63^{a} \pm 0.34$ \\
\hline $\begin{array}{l}\text { Önem } \\
\text { Significance }\end{array}$ & - & - & - \\
\hline
\end{tabular}

BU: Beyaz un, TBU: Tam buğday unu

Önem: $* * P \leq 0.01, * 0.01<P \leq 0.05,-P>0.05$ (önemsiz)

WF: White flour, WWF: Whole wheat flour

Significance: $* * P \leq 0.01, * 0.01<P \leq 0.05,-P>0.05$ (insignificant) 
Çizelge 3. Üretilen ekmeklerin TPA özellikleri Table 3. TP A properties of produced bread

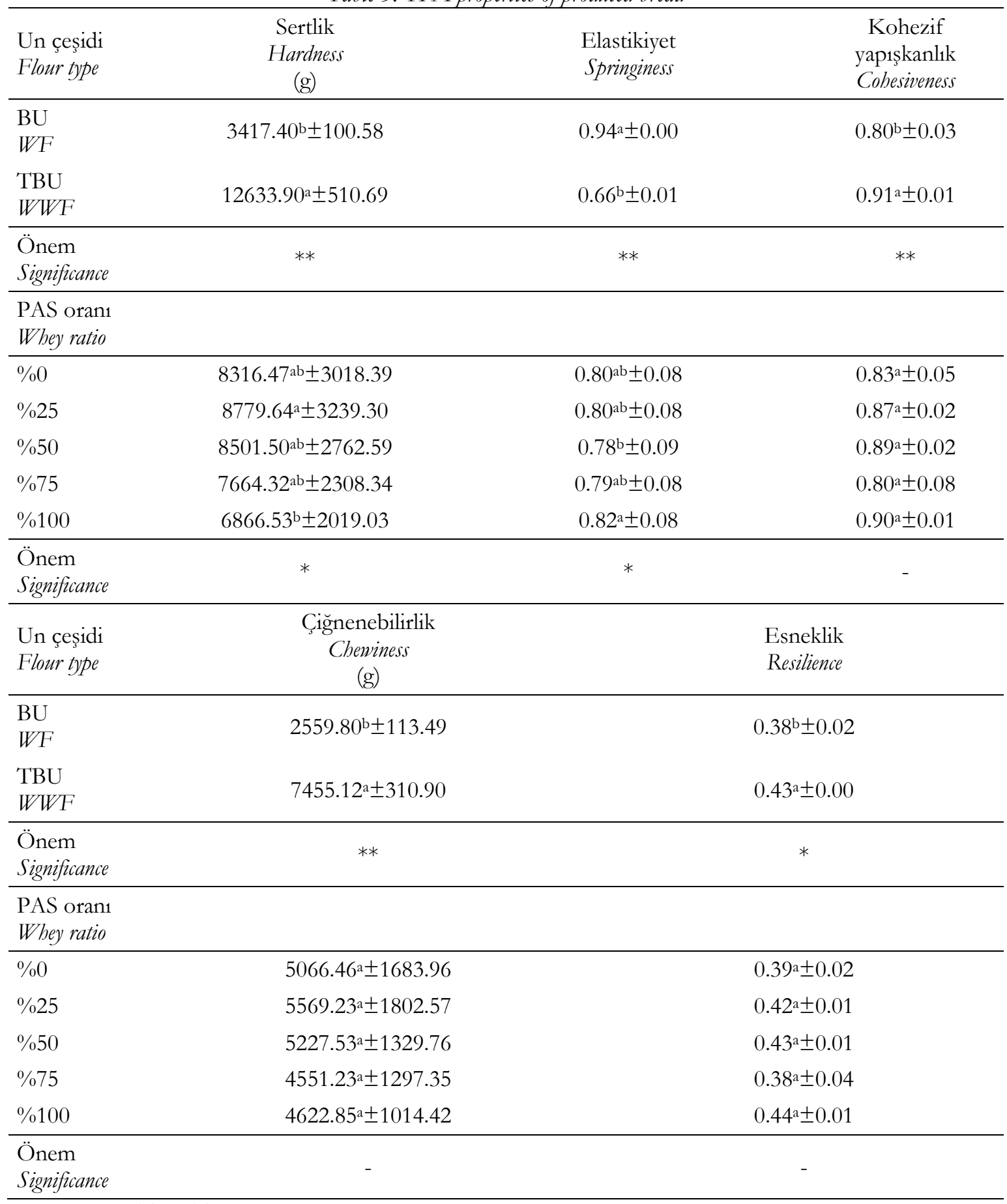

BU: Beyaz un, TBU: Tam buğday unu

Önem: $* * P \leq 0.01, * 0.01<P \leq 0.05,-P>0.05$ (önemsiz)

WF: White flour, WWF: Whole wheat flour

Significance: $* * P \leq 0.01, * 0.01<P \leq 0.05,-P>0.05$ (insignificant) 
Çizelge 4. Üretilen ekmeklerin spesifik hacim değerleri ve bazı kimyasal özellikleri Table 4. Specific volume values and some chemical properties of produced bread

\begin{tabular}{|c|c|c|c|}
\hline $\begin{array}{l}\text { Un çeşidi } \\
\text { Flour type }\end{array}$ & $\begin{array}{l}\text { Spesifik hacim } \\
\text { Specific volume } \\
\left(\mathrm{cm}^{3} / \mathrm{g}\right)\end{array}$ & $\begin{array}{c}\text { Kuru madde } \\
\text { Dry matter } \\
(\%)\end{array}$ & $\begin{array}{c}\mathrm{HMF} \\
H M F \\
(\mathrm{mg} / \mathrm{kg})\end{array}$ \\
\hline $\begin{array}{l}\mathrm{BU} \\
W F\end{array}$ & $2.07^{\mathrm{b}} \pm 0.07$ & $64.32^{\mathrm{b}} \pm 0.30$ & $15.48^{a} \pm 3.33$ \\
\hline $\begin{array}{l}\text { TBU } \\
W W F\end{array}$ & $2.48^{a} \pm 0.04$ & $66.55^{a} \pm 0.13$ & $11.19^{\mathrm{a}} \pm 1.18$ \\
\hline $\begin{array}{l}\text { Önem } \\
\text { Significance }\end{array}$ & $* *$ & $* *$ & - \\
\hline \multicolumn{4}{|l|}{$\begin{array}{l}\text { PAS oran } 1 \\
\text { Whey ratio }\end{array}$} \\
\hline$\% 0$ & $2.07^{b} \pm 0.16$ & $65.35^{\mathrm{ab}} \pm 1.04$ & $7.81^{b} \pm 1.81$ \\
\hline$\% 25$ & $2.29^{\mathrm{ab}} \pm 0.12$ & $64.90^{\mathrm{b}} \pm 0.72$ & $7.36^{\mathrm{b}} \pm 0.78$ \\
\hline$\% 50$ & $2.26^{\mathrm{ab}} \pm 0.18$ & $65.01^{\mathrm{b}} \pm 0.74$ & $11.01^{b} \pm 1.47$ \\
\hline$\% 75$ & $2.44^{a} \pm 0.12$ & $65.75^{\mathrm{ab}} \pm 0.52$ & $19.82^{\mathrm{a}} \pm 3.84$ \\
\hline$\% 100$ & $2.32^{a} \pm 0.09$ & $66.18^{a} \pm 0.25$ & $20.69^{a} \pm 4.97$ \\
\hline $\begin{array}{l}\text { Önem } \\
\text { Significance }\end{array}$ & $*$ & $*$ & $* *$ \\
\hline
\end{tabular}

BU: Beyaz un, TBU: Tam buğday unu

Önem: ** $P \leq 0.01, * 0.01<P \leq 0.05,-P>0.05$ (önemsiz)

WF: White flour, WWF: Whole wheat flour

Significance: ** $P \leq 0.01, * 0.01<P \leq 0.05,-P>0.05$ (insignificant)

Ekmeklerin HMF içeriği üzerine PAS oranının istatistiksel olarak önemli $(P<0.01)$ bir etkisinin olduğu, ancak un çeşidinin önemli bir etkisinin olmadığı tespit edilmiştir. PAS oranının artmasıyla ekmeklerin HMF içeriklerinde tespit edilen artışın PAS bileşiminde bulunan indirgen şeker ve serbest aminoasitlerin Maillard reaksiyonunu arttırmasından kaynaklandığı değerlendirilmiştir. Firın ürünlerinde meydana gelen temel kimyasal reaksiyonlar, enzimatik olmayan esmerleşme reaksiyonları olarak da bilinen Maillard reaksiyonu ve karamelizasyondur. Bu reaksiyonlar sirasinda hem renk ve aroma bileşenleri gibi faydalı, hem de HMF ve akrilamid gibi potansiyel olarak zararlı bileşikler meydana gelmektedir (Capuano vd., 2009; Liu ve Zhong, 2015). Un çeşidi için ise; ortalamalar üzerinden tasviri olarak bir deskriptif değerlendirme yapildığında, tam buğday unu ile üretilen ekmeklerin HMF içeriklerinin, beyaz un ile üretilen ekmeklerin HMF içeriklerinden daha düşük olduğu belirlenmiştir. Tam buğday ununda bulunan kepek materyalinin Maillard reaksiyonunda rol alan reaktantlar1 seyreltmesi nedeniyle bu sonucun elde edildiği değerlendirilmiştir. Capuano vd. (2009) tarafından yapılan bir çalş̧mada da tam buğday unuyla üretilen ekmeklerin HMF içeriğinin normal unla ve çavdar unuyla üretilen ekmeklerin HMF içeriğinden daha düşük olduğu tespit edilmiştir.

\section{Üretilen ekmeklerin duyusal özellikleri}

Farklı çeşit un ve farklı oranda PAS kullanılarak üretilen ekmeklerin bazı duyusal diş (hacim, kabuk rengi, şekil simetrisi, kabuk ve kenar özelliği) ve iç (gözenek yapısı, tat, çiğneme ve tekstür) özelliklerine ait sonuçlar Çizelge 5'te verilmiştir. Ekmeklerin duyusal özelliklerini belirten parametreler panelistlerin beğeni düzeyine göre ifade edilmiş olup bu parametrelerden hiçbirinin üzerine un çeşidi ve PAS ilave oranının istatistiksel olarak etkili olmadığ1 $(P>0.05)$ tespit edilmiştir. PAS ilavesi ile üretilen tüm ekmeklerin panelistler 
tarafindan 5 puanlık duyusal hedonik skalada orta değer olan 3 ve üzerinde puanlandığ ve bu nedenle de ekmeklerin duyusal olarak kabul edilebilir olduğu değerlendirilmiştir.

Çizelge 5. Üretilen ekmeklerin bazı duyusal özellikleri Table 5. Some sensory properties of produced bread

\begin{tabular}{lcccc}
\hline $\begin{array}{l}\text { Un çeşidi } \\
\text { Flour type }\end{array}$ & $\begin{array}{c}\text { Hacim } \\
\text { Volume }\end{array}$ & $\begin{array}{c}\text { Kabuk rengi } \\
\text { Colour of crust }\end{array}$ & $\begin{array}{c}\text { Sekil simetrisi } \\
\text { Symmetry of form }\end{array}$ & $\begin{array}{c}\text { Kabuk ve kenar özelliği } \\
\text { Crust and corner properties }\end{array}$ \\
\hline BU & $4.38^{\mathrm{a}} \pm 0.24$ & $4.24^{\mathrm{a}} \pm 0.10$ & $4.38^{\mathrm{a}} \pm 0.13$ & $4.27^{\mathrm{a}} \pm 0.04$ \\
$W F$ & & & & \\
TBU & $3.16^{\mathrm{a}} \pm 0.33$ & $3.20^{\mathrm{a}} \pm 0.27$ & $3.28^{\mathrm{a}} \pm 0.37$ & $3.81^{\mathrm{a}} \pm 0.31$ \\
$W W F$ & - & & - & \\
\hline Önem & & & & \\
Significance & & & & \\
\hline PAS oran1 & & & $3.20^{\mathrm{a}} \pm 0.94$ & $3.45^{\mathrm{a}} \pm 0.61$ \\
Whey ratio & & $3.35^{\mathrm{a}} \pm 0.61$ & $3.65^{\mathrm{a}} \pm 0.36$ \\
\hline$\% 0$ & $3.35^{\mathrm{a}} \pm 0.95$ & $3.45^{\mathrm{a}} \pm 0.61$ & $3.30^{\mathrm{a}} \pm 0.42$ & $4.30^{\mathrm{a}} \pm 0.12$ \\
$\% 25$ & $3.65^{\mathrm{a}} \pm 0.54$ & $3.85^{\mathrm{a}} \pm 0.32$ & $3.95^{\mathrm{a}} \pm 0.28$ & $4.26^{\mathrm{a}} \pm 0.09$ \\
$\% 70$ & $4.00^{\mathrm{a}} \pm 0.44$ & $3.80^{\mathrm{a}} \pm 0.16$ & $4.10^{\mathrm{a}} \pm 0.25$ & $4.51^{\mathrm{a}} \pm 0.19$ \\
$\% 100$ & $3.30^{\mathrm{a}} \pm 0.19$ & $4.15^{\mathrm{a}} \pm 0.25$ & $4.60^{\mathrm{a}} \pm 0.16$ & \\
\hline
\end{tabular}

Önem

Significance

\begin{tabular}{|c|c|c|c|c|}
\hline $\begin{array}{l}\text { Un çeşidi } \\
\text { Flour type }\end{array}$ & $\begin{array}{l}\text { Gözenek yapis1 } \\
\text { Pore structure }\end{array}$ & $\begin{array}{l}\text { Tat } \\
\text { Flavour }\end{array}$ & $\begin{array}{l}\text { Çiğneme } \\
\text { Chewing }\end{array}$ & $\begin{array}{l}\text { Tekstür } \\
\text { Texture }\end{array}$ \\
\hline $\begin{array}{l}\mathrm{BU} \\
W F\end{array}$ & $3.96^{\mathrm{a}} \pm 0.27$ & $4.30^{a} \pm 0.13$ & $4.36^{a} \pm 0.14$ & $4.34^{\mathrm{a}} \pm 0.12$ \\
\hline $\begin{array}{l}\text { TBU } \\
W W F\end{array}$ & $3.70^{a} \pm 0.19$ & $3.58^{\mathrm{a}} \pm 0.19$ & $3.74 \mathrm{a} \pm 0.19$ & $3.34^{a} \pm 0.23$ \\
\hline $\begin{array}{l}\text { Önem } \\
\text { Significance }\end{array}$ & - & - & - & - \\
\hline \multicolumn{5}{|l|}{$\begin{array}{l}\text { PAS oran1 } \\
\text { Whey ratio }\end{array}$} \\
\hline$\% 0$ & $3.65^{a} \pm 0.50$ & $3.75^{a} \pm 0.41$ & $3.75^{a} \pm 0.30$ & $3.40^{\mathrm{a}} \pm 0.47$ \\
\hline$\% 25$ & $4.40^{a} \pm 0.22$ & $3.65^{a} \pm 0.24$ & $3.90^{\mathrm{a}} \pm 0.30$ & $3.60^{a} \pm 0.50$ \\
\hline$\% 50$ & $4.35^{a} \pm 0.13$ & $3.85^{a} \pm 0.31$ & $4.10^{a} \pm 0.37$ & $4.00^{a} \pm 0.39$ \\
\hline$\% 75$ & $3.45^{a} \pm 0.38$ & $3.95^{\mathrm{a}} \pm 0.24$ & $3.95^{a} \pm 0.17$ & $3.85^{a} \pm 0.10$ \\
\hline$\% 100$ & $3.30^{a} \pm 0.17$ & $4.50^{a} \pm 0.31$ & $4.55^{a} \pm 0.33$ & $4.35^{a} \pm 0.33$ \\
\hline
\end{tabular}

Önem

Significance

BU: Beyaz un, TBU: Tam buğday unu

Önem: $* * P \leq 0.01, * 0.01<P \leq 0.05,-P>0.05$ (önemsiz)

WF: White flour, WWF: Whole wheat flour

Significance: $* * P \leq 0.01, * 0.01<P \leq 0.05,-P>0.05$ (insignificant) 


\section{SONUÇ}

Ekmek üretiminde hamur oluşturucu olarak PAS'in su ikamesi olarak kullanımının hamur oluşumu üzerine olumsuz bir etki yaratmadığı ve ekmeğin fiziksel ve duyusal kalitesini kontrol örneğine göre önemli bir düzeyde azaltmadığ tespit edilmiştir. Ekmek kabuğunda oluşan ve bir işlem kontaminantı olarak kabul edilen HMF içeriğinde ise \%50 PAS ilavesine kadar kontrol örneğine göre önemli bir artış olmadığı, ancak daha yüksek oranlarda PAS ilavesinin HMF düzeyini önemli ölçüde arttırdığı belirlenmiştir.

Sonuç olarak; peynir üretiminin besin içeriği ve ekonomik olarak değerli bir yan ürünü olan, ancak doğrudan çevreye salındığ için önemli bir çevre kirleticisine dönüşen PAS'in ekmek üretiminde $\% 50$ 'ye kadar hamur suyu ikamesi olarak kullanımının uygun olduğu tespit edilmiştir. Böylelikle ekonomik olarak değerli olan bu yan ürünün değerlendirilerek büyük bir ekonomik kaybın engellenebileceği ve bu şekilde hem çevresel bir tehdidin azaltılabileceği hem de ekmeğin besleyici özelliklerinin geliştirilebileceği değerlendirilmiştir.

\section{KAYNAKLAR}

Anonim. (1999). Mikrobiyolojik analiz yöntemlerinde yeni yaklaşımlar. Hemakim A. Ş., İstanbul, Türkiye, $88 \mathrm{~s}$.

Anonim. (2013). Türk Gıda Kodeksi Buğday Unu Tebliği (Tebliğ No: 2013/9). 28606 Sayılı Resmi Gazete, Ankara, Türkiye.

Anonim. (2017). Süt ve Süt Ürünleri Üretim Miktar1. Web Sitesi: https://biruni.tuik.gov.tr/medas $/$ kn $=85 \& l o c a l e$ $=$ tr. Erişim Tarihi: 23.01.2019

APHA. (1976). Compendium of methods for the microbiological examinations of foods. The American Public Health Association, Washington, America, $702 \mathrm{~s}$.

Bilgin, B., Daglioglu, O., Konyali, M. (2006). Functionality of bread made with pasteurized whey and/or buttermilk. ItalJ Food Sci, 18(3): 277286.

Bodnár, I., Alting, A.C., Verschueren, M. (2007). Structural effects on the permeability of whey protein films in an aqueous environment. Food Hydrocoll, 21(5): 889-895.

Capuano, E., Ferrigno, A., Acampa, I., Serpen, A., Açar, Ö.Ç., Gökmen, V., Fogliano, V. (2009). Effect of flour type on Maillard reaction and acrylamide formation during toasting of bread crisp model systems and mitigation strategies. Food Res Int, 42(9): 1295-1302.

Clerici, M.T.P.S., Airoldi, C., El-Dash, A.A. (2009). Production of acidic extruded rice flour and its influence on the qualities of gluten-free bread. LWT-Food Sci Technol, 42(2): 618-623.

Demir, M.K., Elgün, A., Argun, M.Ş. (2009). Sütçülük yan ürünlerinden peynir altı, yayık altı ve süzme yoğurt suları katkılarının bazı ekmek özelliklerine etkileri üzerine bir araştırma. Gıda, 34(2): 99-106.

Divya, N., Rao, K.J. (2010). Studies on utilization of Indian cottage cheese whey in wheat bread manufacture. J Food Process Preserv, 34(6): 975-992.

Doğan, İ.S., Yıldız, Ö. (2009). Ekmek makinelerinde kullanılan farklı bileşen seviyelerinin ekmek kalitesi üzerine etkisi. Gida, 34(5): 295-301.

Elgün, A. (1986). Firın ürünlerinin zenginleştirilmesi açısından peynir altı suyuna bakış. Gıda, 11(3): 145-152.

Elgün, A., Ertugay, Z. (2002). Tabıl işleme teknolojisi. Atatürk Üniversitesi Yayınlar1 No: 718, Erzurum, Türkiye, $411 \mathrm{~s}$.

Elgün, A., Ertugay, Z., Certel, M., Kotancilar, H.G. (2002). Tabul ve ürünlerinde analitik kalite kontrolü ve laboratuar uygulama kelavuzu. Atatürk Üniversitesi Yayınları No: 867, Erzurum, Türkiye, $245 \mathrm{~s}$.

Fallico, B., Zappala, M., Arena, E., Verzera, A. (2004). Effects of conditioning on HMF content in unifloral honeys. Food Chem, 85(2): 305-313.

Gamba, R.R., Moure, C., Diosma, G., Giannuzzi, L., De Antoni, G.L., Pelaez, A.M.L. (2016). Application of whey permeate fermented with kefir grains for the shelf-life improvement of food and feed. Adv Microbiol, 6(9): 650-661. 
Gåmbaro, A., Varela, P., Gimenez, A., Aldrovandi, A., Fiszman, S., Hough, G. (2002). Textural quality of white pan bread by sensory and instrumental measurements. J Texture Stud, 33(5): 401-413.

Gonçalves Cibely, M., de Souza Cínthia Hoch, B., Suguimoto Hélio, H., Ishii Priscila, L., dos Santos Leandro, F. (2017). Addition of whey protein in bread-making: Textural parameters and antioxidant potential of leavened and unleavened bread. Int J Food Eng, 13(4): 1-8.

Guemes-Vera, N., Gonzalez-Victoriano, L., SotoSimental, S., Hernandez-Chavez, J.F., ReyesSantamaria, M.I. (2014). Mechanical properties of cottage cheese-fortified wheat dough and loaf bread. J Food Sci Technol, 51(10): 2797-2802.

Halkman, A.K. (2005). Merck gida mikerobijolojisi uygulamalar. Başak Matbaacılik ve Tanıtım Hizmetleri Ltd. Şti., Ankara, Türkiye, 358 s.

Harding, F. (1999). Milk quality. Aspen Publishers Inc., Gaithersburg, Maryland, UK, 163 s.

ICC. (1976). Method No: 110/1. Determination of the moisture content of cereals and cereal products (Practical method). Approved 1960. ICC Standards, Vienna, Austria.

ICC. (1990). Method No:104/1. Determination of ash in cereals and cereal products. Approved 1960. ICC Standards, Vienna, Austria.

ICC. (1992). Method No:114/1. Method for using the Brabender Extensograph. Approved 1972. ICC Standards, Vienna, Austria.

ICC. (1992). Method No:115/1. Method for using the Brabender Farinograph. Approved 1972. ICC Standards, Vienna, Austria.

ICC. (1994). Method No:105/2. Determination of crude protein in cereals and cereal products for food and for feed. Approved 1980. ICC Standards, Vienna, Austria.

ICC. (1994). Method No:116/1. Determination of the sedimentation value (according to zeleny) as an approximate measure of baking quality. Approved 1972. ICC Standards, Vienna, Austria.

ICC. (1994). Method No:137/1. Mechanical determination of the wet gluten content of wheat flour (Perten Glutomatic). Approved 1982. ICC Standards, Vienna, Austria.

ICC. (1995). Method No:107/1. Determination of the "falling number" according to hagberg - as a measure of the degree of alpha-amylase activity in grain and flour. Approved 1968. ICC Standards, Vienna, Austria.

ISO. (2001). Standard No: ISO 8261:2001 (IDF Standard 122: 2001). Milk and milk products, Preparation of sample and dilutions for microbiological examination. International Organization for Standardization, Geneva, Switzerland.

Kang, I.B., Kim, D.H., Chon, J.W., Seo, K.H. (2018). Effect of microbial control measures on farmstead cheesemaking and antimicrobial resistance of Staphylococcus aureus and Enterococcus spp. isolates. J Food Saf, 38(2): e12432.

Koca, A.F., Tarakçı, Z. (1997). Tarhana üretiminde misır unu ve peyniraltı suyu kullanımı. Gida, 22(4): 287-292.

Kopeć, A., Borczak, B., Pysz, M., Sikora, E., Sikora, M., Curic, D., Novotni, D. (2014). An addition of sourdough and whey proteins affects the nutritional quality of wholemeal wheat bread. Acta scientiarum polonorum. Technologia Alimentaria, 13(1): 43-54.

Kurt, A., Gülümser, S. (1987). Peynir suyu ve kullanım imkânları. Atatürk Üniversitesi Ziraat Fakïltesi Dergisi, 18(1-4): 133-141.

Liu, G., Zhong, Q. (2015). High temperatureshort time glycation to improve heat stability of whey protein and reduce color formation. Food Hydrocoll, 44: 453-460.

Ma, Y., Zhang, L., Wu, Y., Zhou, P. (2019). Changes in milk fat globule membrane proteome after pasteurization in human, bovine and caprine species. Food Chem, 279: 209-215.

Metin, M. (1998). Süt teknolojisi, Sütün bileşimi ve işlenmesi. Ege Üniversitesi Mühendislik Fakültesi Yayınları, Bornova, İzmir, Türkiye, $793 \mathrm{~s}$.

Özkaya, H., Özkaya, B. (2005). Tahıl ve ürünleri analiz yöntemleri. Gida Teknolojisi Derneği Yayınları Yayın No: 31, Ankara, Türkiye, 157 s. 
Paul, S., Kulkarni, S., Rao, K.J. (2016). Effect of Indian cottage cheese (paneer)-whey on rheological and proofing characteristics of multigrain bread dough. J Texture Stud, 47(2): 142151.

Pekcan, G. (2009). Türkiye'de beslenme ve sağllk durumu. Hacettepe Beslenme ve Diyetetik Günleri, II. Mezuniyet Sonrası Eğitim Kursu, 13-22.

Salazar, D.M., Naranjo, M., Perez, L.V., Valencia, A.F., Acurio, L.P., Gallegos, L.M., Alvarez, F.C., Amancha, P.I., Valencia, M.P., Rodriguez, C.A., Arancibia, M.Y. (2017). Development of newly enriched bread with quinoa flour and whey. 3rd International Conference on Agricultural and Biological Sciences, (baş ed.), IOP Publishing, 1$7 \mathrm{~s}$.

Tebben, L., Shen, Y., Li, Y. (2018). Improvers and functional ingredients in whole wheat bread: A review of their effects on dough properties and bread quality. Trends Food Sci Technol, 81: 10-24.
TSE. (1992). Standart No: TSE 4265. DondurmaSüt esasli. Türk Standartlar Enstitüsü, Ankara, Türkiye.

Üçüncü, M. (2004). A'dan Z'ye peynir teknolojisi, Cilt: II. Meta Basim Matbaacillk Hizmetleri, Bornova, İzmir, Türkiye, $1236 \mathrm{~s}$.

Wang, J.G., Tang, J.M., Liu, F., Bohnet, S. (2018). A new chemical marker-model food system for heating pattern determination of microwaveassisted pasteurization processes. Food Bioprocess Technol, 11(7): 1274-1285.

Yerlikaya, O., Kınık, Ö., Akbulut, N. (2010). Peyniraltı suyunun fonksiyonel özellikleri ve peyniraltı suyu kullanılarak üretilen yeni nesil süt ürünleri. Gıda, 35(4): 289-296. 